Juliya Kasaeva,

Sumy State University, Ukraine

\title{
DEVELOPING THE METHODOLOGY OF ASSESSING THE POTENTIAL OF COUNTRIES TO ATTRACT FOREIGN DIRECT INVESTMENT
}

Abstract. To accelerate the transformation process in all spheres of economic and social life the relevance of the adequate assessment of the countries' investment potential was determined in this article. The innovation process has a high impact on the investment potential of the countries through every sector of the economy. As a result, the countries competitiveness depends on the level of technological innovation. The scientific methodological approach to the estimation of countries' investment potential by the adoption of Hurst exponent was proposed. It is based on the magnitude of the accumulated deviation and reflects the economic essence of the concept of potential. As the time series in Hurst exponent calculation, the theoretical (predictive) values of the global attractiveness index were taken. It was determined by the econometric model of the dependence of the effective feature on five integral indicators of the following groups: infrastructure, science and education, ecology and human health, technology, socio-economic conditions. The integrated indexes for each group were calculated by normalizing the input dataset using the relative method, narrowing it with the relative scatter method and generalization with the arithmetic mean. The five-factor nonlinear regression model of the dependence of the global foreign direct investment attractiveness index on five integrated indexes of the groups was created with the Cobb-Douglas function. The calculations were performed for countries such as United States, United Kingdom, Germany, France, Spain, Estonia, the Czech Republic, China, Poland, the Slovak Republic, Romania, Ukraine. This study shows that at the present moment the Slovak Republic, Ukraine and the Czech Republic have the highest investment potential. Therefore, the value of the proper indicator is equal to $60 \%$. At the same time, the lowest investment potential shows the United Kingdom, Spain and Poland, where unused investment opportunities are less than $40 \%$. The obtained results let us define further development opportunities and establish the mechanism for directing the financial resources to the country.

Keywords: Cobb-Douglas production function, FDI, the Hurst exponent, investment appeal, the potential for inward foreign direct investment, regression analysis.

Introduction. Due to the increasing economic globalization, the development of international financial architecture led not only to the free but also very rapid movement of the capital in the world. Investors can buy various assets in any country rather quickly and with moderately low transaction cost (Bilan et al., 2019, Lobanova et al., 2018). However, ones carefully explore not only the cost of agreement and its further profitability but also the country where the asset is located. In the modern business environment during the decision-making process on financing the project, along with economic indicators, investors also try to ensure the social and environmental responsibility of business. Also, a key factor is the level of technology readiness of the asset itself as well as the environment where it is located. That is crucial because after a while, either the asset may not be competitive in the market or the environment will not be technological. As a result, the business centres will move to the other country (Kotikova and Vavrek, 2019). The basic criterion affecting investment decision is also human capital. It can be estimated by the level of science, education and health. Without any doubts, the qualification and education of the workforce ensure business to achieve efficiency under the changing of internal and external operating conditions. Therefore, the governments all around the world are interested in building the favourable investment climate, encouraging the investment of internal and external financial resources in a specific sector of economy or business process, that will lead to its successful transformation and reaching new level of development (Cieślik and Hien Tran, 2019). Thus, it becomes relevant to develop a methodology for

Cite as: Kasaeva, J. (2019). Developing the Methodology of Assessing the Potential of Countries to Attract Foreign Direct Investment. Marketing and Management of Innovations, 4, 292-307. http://doi.org/10.21272/mmi.2019.4-23 
assessing the potential for investment considering not only the socio-economic conditions but also the infrastructure, technology, science and education, environment and human health.

Literature Review. A vital number of scientists all around the world devoted their researches to the evaluation and stimulation of the investment process. The influence of foreign direct investment on economic growth remains the burning issue to modern science. It should be noted that for each country, the impact of investment on the political, economic and social process is different. The role of foreign direct investment in various areas of the economy in the Slovak Republic was studied by Táncošová (2019). The opportunities for economic growth as a result of attracting foreign direct investment to the Republic of India were outlined by Agnihotri and Arora (2019). The impact of investment on economic as well as social processes in the Czech Republic was identified by Hlaváček and Janáček (2019). Besides, Marcel (2019) and Simionescu (2018) determined the power of influence of foreign direct investment on the speed of economic restructuring respectively for the Republic of Benin and Romania. For the overall group of developing countries, the relationship between the investments, economic growth and corruption was found out by Nguedie (2018). A lot of scientific papers are devoted to the evaluation of investment attractiveness from different perspectives. Thus, Goncharuk and Karavan (2013) studied the methods and features measuring investment attractiveness. Kharlamova (2014) evaluated investment attractiveness at the macro level, followed by the ranking of the study objects. Dierkes et al. (2010) worked on forecasting the opportunities for improving the investment attractiveness of the countries and therefore building the investment strategy. Above all, we would like to mention the scientists that study the factors that contribute to drawing foreign direct investment to the country. Thus, Blonigen (2019) identified the motivational factors that intensify investment activities in transnational corporations. Blonigen and Piger (2019) conducted empirical studies of bilateral foreign direct investment, which allows building an effective strategy for purposeful directing the investment in the particular sector of the economy. Nazarczuk and Krajewska (2018) substantiated the determinants of dependence between the foreign direct investment source and distance to the recipient of funds. Ohotina et al. (2018) identified the factors that make the investment climate attractive. The mathematical formalization of the investment-related process is described in studies of Hrytsenko et al. (2017), Kozmenko and Roienko (2013). Thus, the first group of scientists optimized investments based on the territorial principle and the second one determined the most relevant investment activity indicators for the insurance companies. Furthermore, the category of potential for investment and its assessment was considered by Leonov et al. (2014). This group of scientists identified the investors potential in the stock market. At the same time, despite the high number of studies in the investment field, the problem of adequate assessment of the country potential for investment is of paramount importance.

Methodology and research methods. To mathematically describe the evaluation of the market's potential for investment, it is proposed to consider the category potential as an unreachable opportunity. So, that may be defined as a difference between the maximum possible indicator level and its guaranteed value. Besides, we consider not only the difference but also the magnitude of the cumulative deviation that is long-term series memory. Therefore, the model of assessing the potential of markets to attract foreign direct investment will be based on the adopted Hurst exponent (persistence time-series characteristics), calculated based on the magnitude of the accumulated deviation and reflects the economic essence of the concept of potential:

$$
\frac{R}{S}=(\alpha \cdot N)^{H}
$$

where $H$ - the Hurst exponent; $R$ - the magnitude of the accumulated deviation; $S$ - the mean square deviation of the time series; $N$ - the number of periods; $\alpha$-a positive number, given constant.

Therefore, 


$$
H=\frac{\log \left(\frac{R}{S}\right)}{\log (\alpha \cdot N)}
$$

where the magnitude of the accumulated deviation:

$$
\begin{aligned}
& R=\max _{1 \leq u \leq N} Z_{u}-\min _{1 \leq u \leq N} Z_{u} \\
& Z_{u}=\sum_{1}^{u}\left(y_{i}-\bar{y}\right)
\end{aligned}
$$

where $\bar{y}$ - the arithmetic means of the time series; $y_{t}$ - level of the time series.

As the time series for calculation of the Hurst exponent, it is proposed to use the theoretical (forecast) values of the global foreign direct investment attractiveness index, determined by the econometric model dependence of the response variable on five integrated indexes of the following groups: infrastructure, science and education, environment and human health, technology, socio-economic conditions. At the same time, instead of the absolute value of the global foreign direct investment attractiveness index (Table A.1) presented in the form of ranks, it is suggested to select the derived indicator determined by applying Savage normalization (Table 1):

$$
Y_{t}=\frac{\max _{t} y_{t}-y_{t}}{\max _{t} y_{t}-\min _{t} y_{t}}
$$

Table 1. Savage normalization of the global foreign direct investment attractiveness index

\begin{tabular}{|c|c|c|c|c|c|c|}
\hline GFICA index & $\mathbf{2 0 1 3}$ & $\mathbf{2 0 1 4}$ & $\mathbf{2 0 1 5}$ & $\mathbf{2 0 1 6}$ & $\mathbf{2 0 1 7}$ & $\mathbf{2 0 1 8}$ \\
\hline United States & 1.00 & 1.00 & 1.00 & 1.00 & 1.00 & 1.00 \\
\hline United Kingdom & 0.98 & 0.99 & 0.99 & 0.98 & 0.98 & 0.98 \\
\hline Germany & 0.96 & 0.96 & 0.96 & 0.95 & 0.95 & 0.94 \\
\hline France & 0.87 & 0.87 & 0.88 & 0.87 & 0.87 & 0.87 \\
\hline Spain & 0.81 & 0.81 & 0.81 & 0.82 & 0.82 & 0.81 \\
\hline Estonia & 0.79 & 0.80 & 0.80 & 0.81 & 0.79 & 0.79 \\
\hline Czech Republic & 0.78 & 0.78 & 0.78 & 0.78 & 0.78 & 0.78 \\
\hline China & 0.69 & 0.70 & 0.69 & 0.73 & 0.75 & 0.76 \\
\hline Poland & 0.67 & 0.67 & 0.68 & 0.70 & 0.71 & 0.71 \\
\hline Slovakia & 0.65 & 0.66 & 0.64 & 0.65 & 0.65 & 0.65 \\
\hline Romania & 0.56 & 0.55 & 0.59 & 0.60 & 0.58 & 0.58 \\
\hline Ukraine & 0.38 & 0.44 & 0.44 & 0.46 & 0.45 & 0.47 \\
\hline
\end{tabular}

Source: developed by authors.

To build the model that estimates the potential of markets to attract foreign direct investment represented by a regression nonlinear five-factor model, it is proposed to choose a multiplicative model of the Cobb-Douglas function. (Shlafman N., Frolina K., Gotal Dmitrovic L. (2018)):

$$
Y=a_{0} \cdot \prod_{i} x_{i}^{a_{i}}
$$

where $Y$ - response variable, the global foreign direct investment country attractiveness index; $a_{0^{-}}$ econometric model parameter, free term; $x_{i}$ - i-th factor, quantitative assessment of the i-th generalizing characteristic of the corresponding group of indicators for assessing the countries potential for investment; $a_{i}$ - i-th parameter of the econometric model, the degree of $\mathrm{i}$-th explanatory variable.

As the explanatory variables we consider the five integrated indexes of the groups such as infrastructure, science and education, environment and human health, technology, socio-economic condition, so the formula (6) becomes the following:

$$
Y=a_{0} \cdot x_{1}^{a_{1}} \cdot x_{2}^{a_{2}} \cdot x_{3}^{a_{3}} \cdot x_{4}^{a_{4}} \cdot x_{5}^{a_{5}}
$$


where $x_{1}$ - the integrated index of the infrastructure group evaluation; $x_{2}$ - the integrated index of the science and education group evaluation; $x_{3}$ - the integrated index of the environment and human health group evaluation; $x_{4}$-the integrated index of the technology group evaluation; $x_{5}$ - the integrated index of the socio-economic condition group evaluation.

To evaluate the global foreign direct investment country attractiveness index (normalized by the Savage method of the response variable of the model (6)) it is offered to choose the methodology Nardo et al (2005). In turn, the integrated indexes within each group are determined by normalizing the input information base using the relative method (Table 2), followed by weighing with the relative scatter method and summarizing by arithmetic mean method.

Table 2. The input information base for assessing the markets' potential for investment, the 'technology' group

\begin{tabular}{|c|c|c|c|c|c|c|c|}
\hline Country Name & Name & 2013 & 2014 & 2015 & 2016 & 2017 & 2018 \\
\hline 1 & 2 & 3 & 4 & 5 & 6 & 7 & 8 \\
\hline Czech Republic & $\mathrm{T} 1$ & 47.35 & 48.28 & 50.51 & $51.50^{*}$ & $52.39^{*}$ & $53.29^{*}$ \\
\hline Czech Republic & $\mathrm{T} 2$ & 11.10 & 11.66 & 12.02 & 13.39 & 14.02 & $15.39^{*}$ \\
\hline Czech Republic & T3 & 13.11 & 13.42 & 13.54 & 12.72 & 13.33 & $13.80^{*}$ \\
\hline Czech Republic & $\mathrm{T} 4$ & 14.79 & 14.92 & 14.90 & 14.02 & 12.77 & 13.34 \\
\hline Czech Republic & T5 & 1079.87 & 1417.63 & 2048.82 & 11991.39 & 25419.94 & 42361.46 \\
\hline Ukraine & T1 & 42.01 & 31.10 & 30.36 & $31.11^{*}$ & $31.67^{*}$ & $31.59^{*}$ \\
\hline Ukraine & $\mathrm{T} 2$ & 7.88 & 13.72 & 16.92 & 18.56 & 19.48 & $23.18^{*}$ \\
\hline Ukraine & T3 & 0.93 & 0.96 & 0.82 & 0.95 & 0.93 & $0.95^{*}$ \\
\hline Ukraine & T4 & 5.89 & 6.51 & 7.27 & 5.75 & 4.98 & $5.00^{*}$ \\
\hline Ukraine & T5 & 54.03 & 74.70 & 141.80 & 1905.47 & 3948.26 & 6027.81 \\
\hline United Kingdom & T1 & 50.53 & 50.18 & 47.37 & $47.55^{*}$ & $47.82^{*}$ & $48.20^{*}$ \\
\hline United Kingdom & $\mathrm{T} 2$ & 6.83 & 7.34 & 7.37 & 7.57 & 7.37 & $7.57^{*}$ \\
\hline United Kingdom & T3 & 3.82 & 4.16 & 4.10 & 4.50 & 4.25 & $3.89^{*}$ \\
\hline United Kingdom & $\mathrm{T} 4$ & 21.86 & 20.65 & 20.81 & 21.83 & 21.07 & 20.71 \\
\hline United Kingdom & T5 & 2832.50 & 3250.50 & 4385.41 & 8698.55 & 21195.89 & 27250.08 \\
\hline United States & $\mathrm{T} 1$ & 41.17 & 41.17 & 41.17 & $40.59^{*}$ & $40.01^{*}$ & $39.48^{*}$ \\
\hline United States & T2 & 4.91 & 4.68 & 4.84 & 5.08 & 5.29 & $5.33^{*}$ \\
\hline United States & T3 & 8.88 & 8.97 & 9.44 & 9.66 & 9.49 & $9.13^{*}$ \\
\hline United States & T4 & 17.82 & 18.23 & 18.99 & 20.00 & 13.82 & $13.10^{*}$ \\
\hline United States & $\mathrm{T} 5$ & 4303.16 & 5129.54 & 6358.80 & 11435.11 & 30335.70 & 65767.56 \\
\hline Slovak Republic & T1 & 50.02 & 47.52 & 48.19 & $48.98^{*}$ & $50.14^{*}$ & $51.28^{*}$ \\
\hline Slovak Republic & $\mathrm{T} 2$ & 11.02 & 10.49 & 10.50 & 13.01 & 14.85 & $16.06^{*}$ \\
\hline Slovak Republic & T3 & 17.55 & 17.63 & 16.65 & 16.52 & 16.35 & $17.89^{*}$ \\
\hline Slovak Republic & $\mathrm{T} 4$ & 10.31 & 10.22 & 10.29 & 9.88 & 10.93 & $11.67^{*}$ \\
\hline Slovak Republic & T5 & 493.78 & 657.73 & 1068.44 & 3240.78 & 6963.67 & 12992.81 \\
\hline Spain & T1 & 39.65 & 41.80 & 40.24 & $40.59^{*}$ & $41.04^{*}$ & $41.54^{*}$ \\
\hline Spain & $\mathrm{T} 2$ & 8.98 & 9.46 & 9.18 & 9.25 & 9.05 & $9.07^{*}$ \\
\hline Spain & T3 & 1.07 & 1.13 & 1.26 & 1.38 & 1.49 & $1.39^{*}$ \\
\hline Spain & $\mathrm{T} 4$ & 7.67 & 7.00 & 7.15 & 6.98 & 7.05 & $7.00^{*}$ \\
\hline Spain & T5 & 488.33 & 625.85 & 889.57 & 2762.59 & 7247.04 & 11320.67 \\
\hline Romania & $\mathrm{T} 1$ & 41.27 & 40.79 & 37.85 & $38.90^{*}$ & $40.17^{*}$ & $41.55^{*}$ \\
\hline Romania & $\mathrm{T} 2$ & 14.14 & 15.01 & 16.18 & 18.21 & 19.04 & $19.96^{*}$ \\
\hline Romania & T3 & 3.97 & 3.83 & 3.66 & 3.38 & 2.99 & $2.93^{* *}$ \\
\hline
\end{tabular}


Continued Table 2

\begin{tabular}{|l|c|c|c|c|c|c|c|}
\hline \multicolumn{1}{|c|}{$\mathbf{1}$} & $\mathbf{2}$ & $\mathbf{3}$ & $\mathbf{4}$ & $\mathbf{5}$ & $\mathbf{6}$ & $\mathbf{7}$ & $\mathbf{8}$ \\
\hline Romania & T4 & 5.72 & 6.45 & 7.50 & 8.50 & 9.01 & 9.27 \\
\hline Romania & T5 & 175.89 & 246.72 & 361.23 & 3421.47 & 12255.17 & 15938.12 \\
\hline France & T1 & 49.50 & 51.86 & 49.38 & $49.60^{*}$ & $49.82^{*}$ & $50.04^{*}$ \\
\hline France & T2 & 6.68 & 6.93 & 6.74 & 6.67 & 6.66 & $6.56^{*}$ \\
\hline France & T3 & 3.96 & 3.86 & 4.02 & 3.98 & 3.93 & $3.73^{*}$ \\
\hline France & T4 & 25.90 & 26.09 & 26.85 & 26.67 & 23.55 & $23.55^{*}$ \\
\hline France & T5 & 821.35 & 1188.90 & 1897.19 & 6674.45 & 14831.20 & 20414.95 \\
\hline Poland & T1 & 38.02 & 36.96 & 35.45 & $35.84^{*}$ & $36.29^{*}$ & $36.88^{*}$ \\
\hline Poland & T2 & 7.65 & 8.67 & 9.74 & 10.71 & 10.88 & $11.82^{*}$ \\
\hline Poland & T3 & 6.74 & 7.74 & 8.12 & 7.14 & 6.92 & $7.10^{*}$ \\
\hline Poland & T4 & 7.81 & 8.70 & 8.78 & 8.46 & 7.74 & $8.18^{*}$ \\
\hline Poland & T5 & 517.74 & 681.13 & 955.84 & 2492.49 & 6534.93 & 16225.45 \\
\hline China & T1 & 41.38 & 41.38 & 41.38 & $41.36^{*}$ & $41.26^{*}$ & $41.17^{*}$ \\
\hline China & T2 & 8.26 & 9.21 & 11.29 & 12.20 & 12.66 & $15.03^{*}$ \\
\hline China & T3 & 27.42 & 25.94 & 26.56 & 26.50 & 27.07 & $27.59^{*}$ \\
\hline China & T4 & 26.97 & 25.37 & 25.65 & 25.24 & 23.81 & $24.01^{*}$ \\
\hline China & T5 & 5.16 & 9.76 & 19.68 & 47.91 & 209.12 & 446.71 \\
\hline Germany & T1 & 61.02 & 62.20 & 61.40 & $62.01^{*}$ & $62.50^{*}$ & $63.00^{*}$ \\
\hline Germany & T2 & 9.86 & 9.59 & 10.50 & 11.66 & 11.73 & $12.08^{*}$ \\
\hline Germany & T3 & 4.33 & 4.52 & 4.65 & 4.66 & 4.96 & $4.80^{*}$ \\
\hline Germany & T4 & 16.08 & 16.00 & 16.66 & 16.91 & 13.90 & $13.67^{*}$ \\
\hline Germany & T5 & 2601.18 & 3352.79 & 4297.93 & 11624.96 & 34181.28 & 56391.56 \\
\hline Estonia & T1 & 28.88 & 29.22 & 28.81 & $29.47^{*}$ & $30.03^{*}$ & $31.16^{*}$ \\
\hline Estonia & T2 & 8.71 & 9.00 & 8.64 & 9.36 & 10.53 & $11.65^{*}$ \\
\hline Estonia & T3 & 11.61 & 12.80 & 11.91 & 12.53 & 9.28 & $8.81^{*}$ \\
\hline Estonia & T4 & 10.55 & 11.44 & 11.39 & 10.23 & 16.03 & 15.77 \\
\hline Estonia & T5 & 1613.81 & 2194.68 & 3120.71 & 10786.68 & 29131.22 & 48933.90 \\
\hline
\end{tabular}

Note: T1 - medium and high-tech industry (including construction) (\% manufacturing value added); T2 - ICT service exports (\% of service exports, BoP); T3 - ICT goods exports (\% of total goods exports); T4 - high-technology exports (\% of manufactured exports); T5 - secure Internet servers (per 1 million people); ${ }^{*}$ - forecast values calculated by the average growth rate method;

Source: developed by authors.

Normalization the parameters of the input information base involves taking into account both their catalytic and inhibition nature (table 3), the time frame of the study and the spatial sample of the considered list of countries (Boyko, 2011):

$$
n_{t i j c}=\frac{k_{t i j c}}{\max _{t, c} k_{t i j c}}, n_{t i j c}=\frac{\min _{t, c} k_{t i j c}}{k_{t i j c}}
$$

where $n_{t i j c}$ - the normalized value of the i-th indicator $\mathrm{j}$-th group for the $\mathrm{t}$-th year within the c-th country; $k_{t i j c}$ - the actual value of the i-th indicator j-th group for the t-th year within the c-th country; $\max _{t, c} k_{t i j c}\left(\min _{t, c} k_{t i j c}\right)$ - the maximum (respectively minimum) value of the i-th indicator j-th group for the set of considered countries during the studied time frame.

The values of indicators for assessing the countries' potential for investment (on the example of 'technology' group) are normalized according to formula (8) and presented in Table A.2. 
Table 3. The nature of indicators for the assessment of the countries' investment potential

\begin{tabular}{|c|c|c|}
\hline & Infrastructure & Priority \\
\hline 1 & Electric power transmission and distribution losses (\% of output) & inhibitor \\
\hline 2 & Air transport, passengers carried & catalyst \\
\hline 3 & Fixed broadband subscriptions (per 100 people) & catalyst \\
\hline 4 & $\begin{array}{l}\text { Quality of port infrastructure, WEF (1=extremely underdeveloped to 7=well developed } \\
\text { and efficient by international standards) }\end{array}$ & catalyst \\
\hline \multirow[t]{2}{*}{5} & Railways, passengers carried (million passenger-km) & catalyst \\
\hline & Science and education & catalyst \\
\hline 1 & School enrolment, secondary (\% net) & catalyst \\
\hline 2 & Patent applications, residents & catalyst \\
\hline 3 & Research and development expenditure (\% of GDP) & catalyst \\
\hline 4 & Government expenditure on education, total (\% of GDP) & catalyst \\
\hline \multirow[t]{2}{*}{5} & Revenue, excluding grants (\% of GDP) & catalyst \\
\hline & Environment and human health & catalyst \\
\hline 1 & People using safely managed drinking water services (\% of the population) & catalyst \\
\hline 2 & People using at least basic sanitation services (\% of the population) & catalyst \\
\hline 3 & Current health expenditure ( $\%$ of GDP) & catalyst \\
\hline 4 & Adjusted savings: particulate emission damage (\% of GNI) & inhibitor \\
\hline \multirow[t]{2}{*}{5} & Survival to age 65 , male (\% of cohort) & catalyst \\
\hline & Technology & \\
\hline 1 & Medium and high-tech Industry (including construction) (\% manufacturing value-added) & catalyst \\
\hline 2 & Secure Internet servers (per 1 million people) & catalyst \\
\hline 3 & ICT service exports (\% of service exports, BoP) & catalyst \\
\hline 4 & High-technology exports (\% of manufactured exports) & catalyst \\
\hline \multirow[t]{2}{*}{5} & ICT goods exports (\% of total goods exports) & catalyst \\
\hline & Socio-economic conditions & \\
\hline 1 & Foreign direct investment, nett inflows (\% of GDP) & catalyst \\
\hline 2 & Adjusted net national income (annual \% growth) & catalyst \\
\hline 3 & $\begin{array}{l}\text { Labour force participation rate, total (\% of total population ages } 15-64 \text { ) (modelled ILO } \\
\text { estimate) }\end{array}$ & catalyst \\
\hline 4 & Self-employed, total (\% of total employment) (modelled ILO estimate) & catalyst \\
\hline 5 & Wage and salaried workers, total (\% of total employment) (modelled ILO estimate) & catalyst \\
\hline
\end{tabular}

Source: developed by authors.

The list of chosen indicators has different priorities in the general variation of the response variable, so there is a need to calculate the weight coefficients. The indicators weight is calculated by the relative to scatter method, that allows calculating the degree of influence using an objective approach, and it considers the economic essence of the potential:

$$
w_{i j c t}=\frac{\gamma_{i j c t}}{\sum_{t} \gamma_{i j c t}}, \gamma_{i j c t}=\frac{\max _{t} k_{t i j c}-\min _{t} k_{t i j c}}{\max _{t} k_{t i j c}}=1-\frac{\min _{t} k_{t i j c}}{\max _{t} k_{t i j c}}
$$

where $w_{i j c t}$ - the weight coefficient of the i-th indicator for assessing the country investment potential within the j-th group for the $\mathrm{t}$-th year for the c-th country; $\max _{t} k_{t i j c}$ - the maximum value of the i-th indicator for assessing the country investment potential within the $\mathrm{j}$-th group during $t$ years for the $c$-th country; $\min _{t} k_{t i j c}$ - the minimum value of the i-th indicator for assessing the country investment potential within

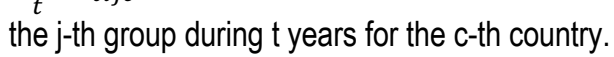


Formula (9) can be represented as follows:

$$
w_{i j c t}=\frac{\gamma_{i j c t}}{\sum_{t} \gamma_{i j c t}}=\frac{\frac{\max _{t} k_{t i j c}-\min _{t} k_{t i j c}}{\max _{t} k_{t i j c}}}{\sum_{t} \frac{\max _{t} k_{t i j c}-\min _{t} k_{t i j c}}{\max _{t} k_{t i j c}}}==\left(1-\frac{\min _{t} k_{t i j c}}{\max _{t} k_{t i j c}}\right) / \sum_{t}\left(1-\frac{\min _{t} k_{t i j c}}{\max _{t} k_{t i j c}}\right)
$$

So, having assessed the indicators priority for evaluating the countries' investment potential using formula (10), we arrange the results in a table format (table 4).

Table 4. The weighted coefficients of the priority of indicators for assessing the countries' investment potential

\begin{tabular}{|c|c|c|c|c|c|c|c|}
\hline Country Name & Name & o & $\mathbf{w}$ & Country Name & Name & 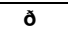 & $\mathbf{w}$ \\
\hline Czech Republic & T1 & 0.30 & 0.0892 & Romania & T1 & 0.45 & 0.1293 \\
\hline Czech Republic & $\mathrm{T} 2$ & 0.92 & 0.2704 & Romania & T2 & 0.58 & 0.1677 \\
\hline Czech Republic & T3 & 0.71 & 0.2079 & Romania & T3 & 0.74 & 0.2155 \\
\hline Czech Republic & $\mathrm{T} 4$ & 0.48 & 0.1400 & Romania & $\mathrm{T} 4$ & 0.68 & 0.1977 \\
\hline Czech Republic & T5 & 1.00 & 0.2925 & Romania & T5 & 1.00 & 0.2898 \\
\hline Ukraine & $\mathrm{T1}$ & 0.51 & 0.1372 & France & T1 & 0.13 & 0.0503 \\
\hline Ukraine & $\mathrm{T} 2$ & 0.95 & 0.2563 & France & $\mathrm{T} 2$ & 0.38 & 0.1527 \\
\hline Ukraine & T3 & 0.71 & 0.1906 & France & T3 & 0.67 & 0.2701 \\
\hline Ukraine & T4 & 0.55 & 0.1472 & France & T4 & 0.31 & 0.1252 \\
\hline Ukraine & $\mathrm{T} 5$ & 1.00 & 0.2687 & France & T5 & 1.00 & 0.4017 \\
\hline United Kingdom & $\mathrm{T1}$ & 0.17 & 0.0598 & Poland & $\mathrm{T1}$ & 0.30 & 0.0883 \\
\hline United Kingdom & $\mathrm{T} 2$ & 0.39 & 0.1362 & Poland & $\mathrm{T} 2$ & 0.78 & 0.2306 \\
\hline United Kingdom & T3 & 0.82 & 0.2898 & Poland & T3 & 0.60 & 0.1785 \\
\hline United Kingdom & T4 & 0.46 & 0.1615 & Poland & T4 & 0.70 & 0.2066 \\
\hline United Kingdom & T5 & 1.00 & 0.3527 & Poland & T5 & 1.00 & 0.2960 \\
\hline United States & T1 & 0.23 & 0.0884 & China & T1 & 0.06 & 0.0214 \\
\hline United States & $\mathrm{T} 2$ & 0.23 & 0.0856 & China & $\mathrm{T} 2$ & 0.95 & 0.3280 \\
\hline United States & T3 & 0.57 & 0.2165 & China & T3 & 0.43 & 0.1506 \\
\hline United States & T4 & 0.62 & 0.2329 & China & T4 & 0.44 & 0.1534 \\
\hline United States & T5 & 1.00 & 0.3766 & China & T5 & 1.00 & 0.3467 \\
\hline Slovak Republic & T1 & 0.34 & 0.0908 & Germany & T1 & 0.17 & 0.0673 \\
\hline Slovak Republic & $\mathrm{T} 2$ & 0.86 & 0.2271 & Germany & $\mathrm{T} 2$ & 0.54 & 0.2169 \\
\hline Slovak Republic & T3 & 0.86 & 0.2262 & Germany & T3 & 0.50 & 0.2005 \\
\hline Slovak Republic & T4 & 0.72 & 0.1916 & Germany & T4 & 0.29 & 0.1145 \\
\hline Slovak Republic & T5 & 1.00 & 0.2643 & Germany & T5 & 1.00 & 0.4008 \\
\hline Spain & T1 & 0.25 & 0.0980 & Estonia & T1 & 0.52 & 0.1298 \\
\hline Spain & $\mathrm{T} 2$ & 0.18 & 0.0691 & Estonia & $\mathrm{T} 2$ & 0.82 & 0.2065 \\
\hline Spain & T3 & 0.79 & 0.3056 & Estonia & T3 & 0.82 & 0.2066 \\
\hline Spain & T4 & 0.36 & 0.1397 & Estonia & T4 & 0.82 & 0.2059 \\
\hline Spain & T5 & 1.00 & 0.3875 & Estonia & T5 & 1.00 & 0.2512 \\
\hline
\end{tabular}

Source: developed by authors.

Normalizing the input dataset by the relative method and weighing by the relative scatter method we determine the integrated index in each group by the arithmetic mean:

$$
I_{j c t}=\frac{\sum_{1}^{T} n_{t i j c}{ }^{w_{i j c t}}}{T}
$$


where $I_{j c t}$ - the integrated index for assessing the j-th group as a characteristic of the potential for investment of the c-th country for $\mathrm{t}$-th year; $T$ - the total number of years of the studied time frame.

The results of calculations by formula (11) for five groups are presented in tabular form (table A3-A7).

Results. Considering the intermediate calculations of the input dataset concerning the relative normalization, defining the weight of coefficients by the relative scatter method and generalization by the arithmetic mean, formula (7) is:

$$
Y_{c t}=a_{0} \cdot \prod_{j} I_{j c t}^{a_{i}}=a_{0} \cdot I_{1 c t}^{a_{1}} \cdot I_{2 c t}^{a_{2}} \cdot I_{3 c t}^{a_{3}} \cdot I_{4 c t}^{a_{4}} \cdot I_{5 c t}^{a_{5}}
$$

To estimate the parameters of the multivariate nonlinear regression equation (12), we suggest using the method of least-squares (Kuzmenko and Kyrkach, 2014), which requires preliminary linearization:

$$
\ln Y_{c t}=\ln a_{0}+a_{1} \cdot \ln I_{1 c t}+a_{2} \cdot \ln I_{2 c t}+a_{3} \cdot \ln I_{3 c t}+a_{4} \cdot \ln I_{4 c t}+a_{5} \cdot \ln I_{5 c t}
$$

The introduction of symbols $\ln Y_{c t}=Y_{c t}^{*}, \ln a_{0}=a_{0}^{*}, \ln I_{1 c t}=I_{1 c t}^{*}, \ln I_{2 c t}=I_{2 c t}^{*}, \ln I_{3 c t}=I_{3 c t}^{*}$, $\ln I_{4 c t}=I_{4 c t}^{*}, \ln I_{5 c t}=I_{5 c t}^{*}$ let us get a linear multivariate regression equation:

$$
Y_{c t}^{*}=a_{0}^{*}+a_{1} \cdot I_{1 c t}^{*}+a_{2} \cdot I_{2 c t}^{*}+a_{3} \cdot I_{3 c t}^{*}+a_{4} \cdot I_{4 c t}^{*}+a_{5} \cdot I_{5 c t}^{*}
$$

The application of the least-squares method for estimating the parameters of the linearized regression equation (14) requires preliminary systematization of the response variable (the global foreign direct investment attractiveness index) from 2013 to 2018, explanatory variables - integrated index of groups: infrastructure, science and education, environment and human health, technology, socio-economic conditions (Table 5).

Table 5. Actual and predicted values of the global foreign direct investment attractiveness index, the results of intermediate calculations

\begin{tabular}{|l|c|c|c|c|c|c|c|}
\hline & $\begin{array}{c}\text { GFICA } \\
\text { index }\end{array}$ & Infrastructure & $\begin{array}{c}\text { Science } \\
\text { and } \\
\text { education }\end{array}$ & $\begin{array}{c}\text { Environment } \\
\text { and human } \\
\text { health }\end{array}$ & Technology & $\begin{array}{c}\text { Socio- } \\
\text { economic } \\
\text { conditions }\end{array}$ & $\begin{array}{c}\text { GFICA } \\
\text { index } \\
\text { prediction }\end{array}$ \\
\hline 2013 & 0.9630 & 0.8497 & 0.6689 & 0.9057 & 0.7390 & 0.7020 & 0.9630 \\
\hline 2014 & 0.9630 & 0.8588 & 0.6706 & 0.9088 & 0.7452 & 0.7098 & 0.9630 \\
\hline 2015 & 0.9630 & 0.8755 & 0.6702 & 0.9073 & 0.7562 & 0.7461 & 0.9630 \\
\hline 2016 & 0.9537 & 0.8876 & 0.6716 & 0.9075 & 0.7934 & 0.7411 & 0.9537 \\
\hline 2017 & 0.9537 & 0.9047 & 0.6730 & 0.9075 & 0.8454 & 0.7367 & 0.9537 \\
\hline 2018 & 0.9444 & 0.9297 & 0.6745 & 0.9086 & 0.8796 & 0.7431 & 0.9444 \\
\hline
\end{tabular}

Source: developed by authors.

To calculate the parameters in the equation (14) we used the MS Excel package, the Regression tab in Data Analysis, as a result, we obtained the following results (Table 6). Formula (12) in the case of Germany takes the following form:

$$
Y_{G t}=\exp (-13.1884) \cdot I_{1 c t}^{-0.8466} \cdot I_{2 c t}^{-40.9234} \cdot I_{3 c t}^{28.7691} \cdot I_{4 c t}^{1.6472} \cdot I_{5 c t}^{0.2635}
$$

We systematize in a tabular form the obtained results in the context of spatial analysis of the studied range of countries (Table 7). 
Table 6. The parameters of the regression equation, dependency of global foreign direct investment attractiveness index on the integrated indexes of the groups

\begin{tabular}{|c|c|c|c|}
\hline & Coefficients & Lower 95\% & Upper 95\% \\
\hline Intercept & -13.1884 & -13.1884 & -13.1884 \\
\hline Infrastructure & -0.8466 & -0.8466 & -0.8466 \\
\hline Science and education & -40.9234 & -40.9234 & -40.9234 \\
\hline Environment and human health & 28.7691 & 28.7691 & 28.7691 \\
\hline Technology & 1.6472 & 1.6472 & 1.6472 \\
\hline Socio-economic conditions & 0.2635 & 0.2635 & 0.2635 \\
\hline
\end{tabular}

Source: developed by authors.

Table 7. The parameters of regression equations, the dependency of the global foreign direct investment attractiveness index on integrated indexes of the groups within the studied range of countries

\begin{tabular}{|c|c|c|c|c|c|c|}
\hline & Intercept & Infrastructure & $\begin{array}{c}\text { Science } \\
\text { and } \\
\text { education }\end{array}$ & $\begin{array}{c}\text { Environment } \\
\text { and human } \\
\text { health }\end{array}$ & $\begin{array}{c}\text { Sochnology } \\
\text { economic } \\
\text { conditions }\end{array}$ \\
\hline United States & 0.1397 & -0.0088 & 0.9426 & 0.0135 & -0.0305 & -0.0073 \\
\hline United Kingdom & 1.8287 & -0.0774 & 8.8417 & -1.7571 & 0.0163 & 0.0954 \\
\hline Germany & -13.1884 & -0.8466 & -40.9234 & 28.7691 & 1.6472 & 0.2635 \\
\hline France & -0.0352 & 0.0088 & 0.4940 & 0.8186 & -0.2652 & 0.1839 \\
\hline Spain & -3.4944 & 1.0769 & -10.4343 & 0.0216 & -1.0665 & -0.1907 \\
\hline Estonia & -0.4696 & 0.7328 & -1.7776 & -0.3353 & -0.1369 & -0.0140 \\
\hline Czech Republic & -0.1298 & -0.1299 & 0.0710 & 1.0867 & -0.0013 & -0.0266 \\
\hline China & 17.8123 & -11.4846 & -0.6141 & 38.7841 & 2.9906 & 2.9801 \\
\hline Poland & 1.6158 & -2.2024 & 2.0908 & 11.2415 & 0.2221 & -0.2584 \\
\hline Slovakia & -1.4284 & 0.8469 & -1.6892 & -4.3787 & -0.0142 & -0.0117 \\
\hline Romania & 1.5470 & -1.6463 & 2.8131 & 12.4151 & -0.2044 & -1.5099 \\
\hline Ukraine & 5.2646 & -24.1373 & 21.4112 & -5.0143 & 12.7559 & -1.7160 \\
\hline
\end{tabular}

Source: developed by authors.

In this paper, a scientific and methodological approach to assessing the country's potential for investment by adapting the Hurst exponent is proposed, which is based on intermediate calculations of $Z_{u}$ depending on the year of observation and R/S on the accumulated number of observations (Table 8).

Table 8. Intermediate calculations of assessing the potential for investment as the Hurst exponent for Germany

\begin{tabular}{|c|c|c|c|c|c|c|}
\hline & $\mathbf{2 0 1 3}$ & $\mathbf{2 0 1 4}$ & $\mathbf{2 0 1 5}$ & $\mathbf{2 0 1 6}$ & $\mathbf{2 0 1 7}$ & $\mathbf{2 0 1 8}$ \\
\hline GFICA index & 0.9630 & 0.9630 & 0.9630 & 0.9537 & 0.9537 & 0.9444 \\
\hline $\mathrm{Z}$ & 0.0062 & 0.0062 & 0.0062 & -0.0031 & -0.0031 & -0.0123 \\
\hline $\mathrm{n}$ & 2 & 3 & 4 & 5 & 6 & \\
\hline $\mathrm{R} / \mathrm{S}$ & 1.4142 & 1.8813 & 2.0000 & 1.8257 & 2.4495 & \\
\hline
\end{tabular}

Source: developed by authors.

The data collected in table 8 reflects the calculation of the Hurst exponent - the degree of non-linear function, that is presented in Figure 1. 


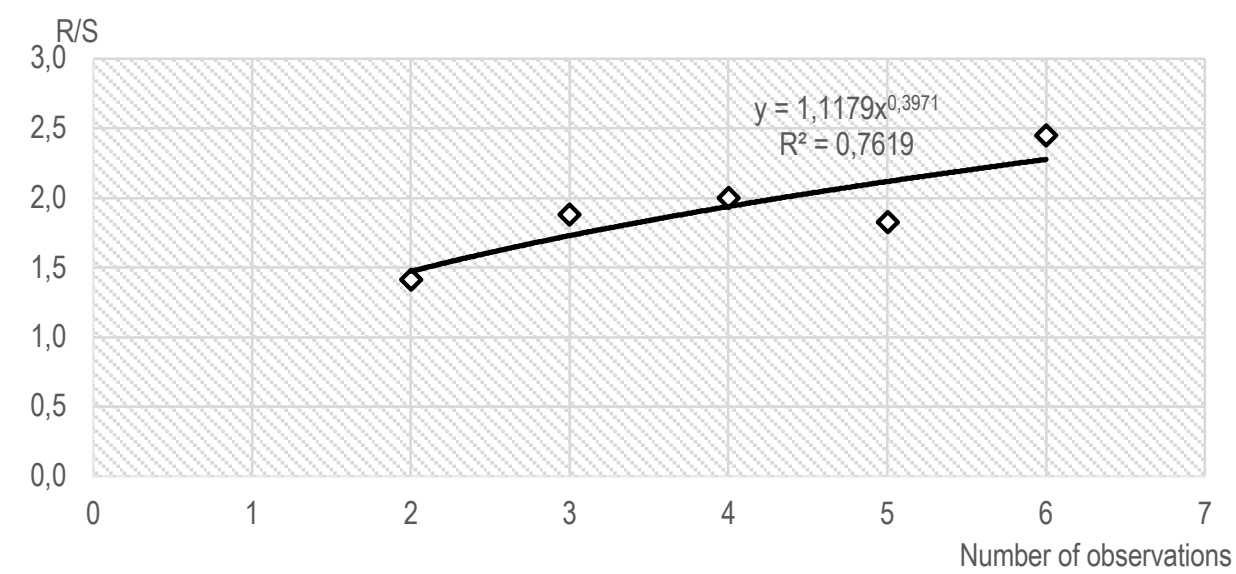

Figure 1. The dependence of the R/S indicator on the accumulated number of observations for

Source: developed by authors.

Germany

The graph in Figure 1 depicts the ratio of the magnitude of cumulative deviation to the standard deviation of the time series of the global foreign direct investment country attractiveness index, and its dependence on the number of years when the accumulated effect of the created investment conditions are considered. This dependence is presented as a correlated field of points. The trend line as the nonlinear power function demonstrates the dependencies between them. The received nonlinear function allows defining the indicator of the potential for investment by determining the exponent of the variable that is the Hurst exponent. The coefficient of determination value is equal to $78 \%$ and it confirms the adequacy of the calculations. Making the same calculations as in the case of Germany, allows us to get the following data of the spatial analysis within the studied countries. (Figure 2)

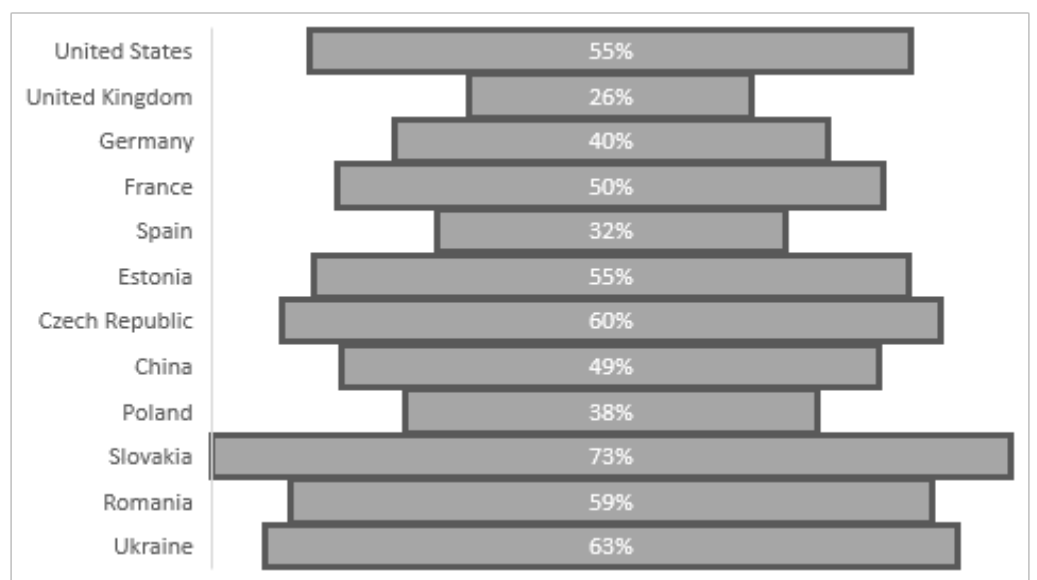

Figure 2. Potential for the investment of the studied countries spatial analysis Source: developed by authors. 
Thus, based on the calculations, we single out four groups of countries according to its potential for investment. So, the first group is characterized by the potential for investment less than $40 \%$ and includes the UK, Spain and Poland. That means the potential for investment under the current economic conditions is used by more than $60 \%$ in these countries. As for the UK, it should be noted that Brexit made a significant impact on the country's potential for investment. Therefore, it is characterized by the minor value of the effective indicator. For Poland, the defined measure of the potential for investment is quite reasonable, since it has been using it very actively and had a rapid economic development recently. A low value of investment potential in Spain is determined by the need to transform state policy and investment infrastructure, as for now, it does not attract external and internal investors. The next group of countries consists of Germany, China and France. For them, the potential for investment is within $40-50 \%$. These figures indicate that the countries are using the available opportunities effectively, but they also have significant reserves to encourage investment resources in the future. The third group includes Estonia, the USA and Romania with the potential for investment between $50-60 \%$. While Estonia and the USA economies are characterized by technological innovation and the most comfortable IT ecosystem, that under the condition of Industry 4.0, attracts investors the most. Romania with the investment potential of $59 \%$ has a low level of investment climate and insignificant use of available opportunities to attract free financial resources to the economy. The last group of countries with the highest level of potential for investment (over 60\%) includes the Czech Republic, Ukraine and the Slovak Republic. For the Czech Republic, the level of $60 \%$ demonstrates missed opportunities that must be used and therefore significant economic effect will be achieved. On top of that, all the necessary elements of an attractive investment climate exist in the country. In turn, Ukraine and the Slovak Republic must go through significant political, infrastructural and financial transformations to turn the existing potential into the real attracted financial flows into the economy. Thus, we can conclude that the calculations are fully consistent with the current economic conditions and confirm the adequacy of the proposed methodology for assessing the potential for investment.

Conclusions. Thus, the developed methodology for assessing the country's potential to attract the investments includes four stages: 1) dividing the set of input indicators into five groups: infrastructure, science and education, environment and human health, technology, socio-economic conditions; 2) calculation of the integrated index for each group by normalizing the input dataset by the relative method, narrowing it using the relative scatter method and generalization with the arithmetic mean; 3 ) the development of the five-factor nonlinear regression model of the dependence of the global foreign direct investment attractiveness index on five integrated indexes of the groups with the Cobb-Douglas function; 4) assessment of the country potential to attract the investments by adapting the Hurst exponent. The obtained quantitative characteristic of the country potential for investment allows us to assess the scope of opportunities for the further development of economic processes and establish the effective encouragement mechanism for directing the investment resources into the country.

\section{References}

Agnihotri, A.N., Arora, S.H. Study of Linkages Between Outward Foreign Direct Investment (OFDI) and Domestic Economic Growth: an Indian Perspective. Financial Markets, Institutions and Risks, 2019, 3(1), pp. $43-49$.

Bilan, Y., Rubanov, P., Vasylieva, T., Lyeonov, S. The influence of industry 4.0 on financial services: Determinants of alternative finance development. Polish Journal of Management Studies, 2019, 19(1), pp. 70-93.

Blonigen, B. A. Foreign direct investment. Foreign Direct Investment (pp. 1-538). World Scientific Publishing Co., 2019 https://doi.org/10.1142/11176

Blonigen, B. A., \& Piger, J. Determinants of foreign direct investment. In Foreign Direct Investment (pp. 3-54). World Scientific Publishing Co., 2019. https://doi.org/10.1142/9789813277014_0001 
Boyko, A.O. Insurance company portfolio optimization based on reinsurance operations usage. Actual Problems of Economics, 2011, № 1(115), pp. C. 160-169

Cieślik, A., \& Hien Tran, G. Determinants of outward FDI from emerging economies. Equilibrium. Quarterly Journal of Economics and Economic Policy, 2091, 14(2), pp. 209-231. https://doi.org/10.24136/eq.2019.010

Dierkes, M., Erner, C., \& Zeisberger, S. Investment horizon and the attractiveness of investment strategies: A behavioral approach. Journal of Banking and Finance, 2010,34(5), pp. 1032-1046. https://doi.org/10.1016/j.jbankfin.2009.11.003

Fagerberg, J., Srholec, M., Verspagen, B. (2010). The Role of Innovation in Development. Review of Economics and Institutions. 1. 10.5202/rei.v1i2.15.

Goncharuk, A.G., Karavan, S. The investment attractiveness evaluation: methods and measurement features. Polish Journal of Management Studies, 2013, (7), pp. 161-167.

Hlaváček, P., Janáček, J. The influence of foreign direct investment and public incentives on the socio-economic development of regions: an empirical study from the czech republic. E a M: Ekonomie a Management, 2019, 22(3), pp. 4-19. https://dx.doi.org/10.15240/tul/001/2019-3-001

Hrytsenko, L., Shevchenko, H., Daher, K. The economic optimization of investment into the territorial development of recreation. SocioEconomic Challenges, 2017, 1(2), pp. 59-79. http://doi.org/10.21272/sec.1(2).59-79.2017

Kharlamova, G. Investment attractiveness of Ukrainian regions: rating assessment and marketing promotion. Journal of International Studies, 2014, 7(1), pp. 9-26. http://doi.org/10.14254/2071-8330.2014/7-1/1

Kotikova, S., \& Vavrek, R. Determining the size of technological gap between local firms and foreign direct investment at regional level. Journal of International Studies, 2019, 12(3), pp. 48-63.

Kozmenko, O., Roienko, V. Evaluation and use of indicators of insurance companies' investment activities. Investment Management and Financial Innovations, 2013, 10(3), pp. 98-105.

Kuzmenko, O., Kyrkach, S. The use of regression analysis in the financial planning of banks, mathematical formalization of the stages of financial planning in banks. Banks and Bank Systems, 2014, 9(1), pp. 120-126

Leonov, S.V., Frolov, S., Plastun, V. Potential of institutional investors and stock market development as an alternative to households' savings allocation in banks. Economic Annals-XXI, 2014, 11-12, pp. 65-68.

Lobanova, J., Kračun, D., Kavkler, A. Effects of cross-border mergers and acquisitions on GDP per capita and domestic investment in transition countries. Journal of Business Economics and Management, 2018, 19(1), pp. 124137. https://doi.org/10.3846/16111699.2017.1408677

Marcel, D. T. A. M. Impact of the Foreign Direct Investment on Economic growth on the Re-public of Benin. Financial Markets, Institutions and Risks, 2019, 3(2), pp. 69-78. http://doi.org/10.21272/fmir.3(2).69-78.2019. Nazarczuk, J. M., \& Krajewska, A. Local determinants of foreign direct investment in Poland: the role of relative distance. Equilibrium. Quarterly Journal of Economics and Economic Policy, 2018, 13(1), pp. 73-88.

Nguedie, Y. H. N. Corruption, Investment and Economic Growth in Developing Countries: A Panel Smooth Transition Regression Approach. SocioEconomic Challenges, 2018, 2(1), pp. 63-68.

Ohotina, A., Ignatjeva, S., Lavrinenko, O., Lonska J. Socioeconomic security as a factor of the investment climate in the region. Journal of Security and Sustainability, 2018, Issues 7(3), pp. 427-438.

Simionescu, M. Effects of European economic integration on foreign direct investment: The case of Romania. Economics and Sociology, 2018, 11(4), pp. 96-105. http://doi.org/10.14254/2071-789X.2018/11-4/6

Táncošová, J. The role of foreign direct investment in the economy of Slovakia. Entrepreneurship and Sustainability, 2019, Issues 6(4), pp. 2127-2135. https://doi.org/10.9770/jesi.2019.6.4(40) 


\section{Annexes}

Table A.1. Dynamics of the global foreign direct investment attractiveness index, country ranking

\begin{tabular}{|l|c|c|c|c|c|c|}
\hline \multicolumn{1}{|c|}{ GFICA index } & $\mathbf{2 0 1 3}$ & $\mathbf{2 0 1 4}$ & $\mathbf{2 0 1 5}$ & $\mathbf{2 0 1 6}$ & $\mathbf{2 0 1 7}$ & $\mathbf{2 0 1 8}$ \\
\hline United States & 1 & 1 & 1 & 1 & 1 & 1 \\
\hline United Kingdom & 3 & 2 & 2 & 3 & 3 & 3 \\
\hline Germany & 5 & 5 & 5 & 6 & 6 & 7 \\
\hline France & 15 & 15 & 14 & 15 & 15 & 15 \\
\hline Spain & 22 & 22 & 21 & 20 & 20 & 21 \\
\hline Estonia & 24 & 23 & 23 & 22 & 24 & 24 \\
\hline Czech Republic & 25 & 25 & 25 & 25 & 25 & 25 \\
\hline China & 34 & 33 & 35 & 30 & 28 & 27 \\
\hline Poland & 37 & 37 & 36 & 33 & 32 & 32 \\
\hline Slovakia & 39 & 38 & 40 & 39 & 39 & 39 \\
\hline Romania & 48 & 50 & 45 & 44 & 46 & 46 \\
\hline Ukraine & 68 & 62 & 61 & 59 & 60 & 58 \\
\hline
\end{tabular}

Source: A Global Foreign Direct Investment Country Attractiveness Index.

Table A.2. Dynamics of the normalized values within parameters of the 'technology' group

\begin{tabular}{|c|c|c|c|c|c|c|c|}
\hline Country Name & Name & 2013 & 2014 & 2015 & 2016 & 2017 & 2018 \\
\hline 1 & 2 & 3 & 4 & 5 & 6 & 7 & 8 \\
\hline Czech Republic & T1 & 0.97 & 0.98 & 0.98 & 0.98 & 0.98 & 0.99 \\
\hline Czech Republic & T2 & 0.82 & 0.83 & 0.84 & 0.86 & 0.87 & 0.90 \\
\hline Czech Republic & T3 & 0.84 & 0.84 & 0.84 & 0.83 & 0.84 & 0.85 \\
\hline Czech Republic & T4 & 0.89 & 0.89 & 0.89 & 0.88 & 0.87 & 0.88 \\
\hline Czech Republic & T5 & 0.30 & 0.33 & 0.36 & 0.61 & 0.76 & 0.88 \\
\hline Ukraine & T1 & 0.95 & 0.91 & 0.90 & 0.91 & 0.91 & 0.91 \\
\hline Ukraine & $\mathrm{T} 2$ & 0.76 & 0.87 & 0.92 & 0.94 & 0.96 & 1.00 \\
\hline Ukraine & T3 & 0.51 & 0.52 & 0.50 & 0.52 & 0.51 & 0.52 \\
\hline Ukraine & $\mathrm{T} 4$ & 0.77 & 0.78 & 0.80 & 0.77 & 0.75 & 0.75 \\
\hline Ukraine & T5 & 0.15 & 0.16 & 0.19 & 0.39 & 0.47 & 0.53 \\
\hline United Kingdom & T1 & 0.99 & 0.99 & 0.98 & 0.98 & 0.98 & 0.98 \\
\hline United Kingdom & $\mathrm{T} 2$ & 0.85 & 0.86 & 0.86 & 0.86 & 0.86 & 0.86 \\
\hline United Kingdom & T3 & 0.55 & 0.56 & 0.56 & 0.57 & 0.56 & 0.55 \\
\hline United Kingdom & $\mathrm{T4}$ & 0.93 & 0.92 & 0.92 & 0.93 & 0.92 & 0.92 \\
\hline United Kingdom & T5 & 0.33 & 0.35 & 0.38 & 0.49 & 0.67 & 0.73 \\
\hline United States & T1 & 0.96 & 0.96 & 0.96 & 0.96 & 0.96 & 0.96 \\
\hline United States & T2 & 0.88 & 0.87 & 0.87 & 0.88 & 0.88 & 0.88 \\
\hline United States & T3 & 0.76 & 0.77 & 0.77 & 0.78 & 0.78 & 0.77 \\
\hline United States & T4 & 0.86 & 0.86 & 0.87 & 0.88 & 0.81 & 0.80 \\
\hline United States & T5 & 0.36 & 0.38 & 0.41 & 0.52 & 0.75 & 1.00 \\
\hline Slovak Republic & T1 & 0.98 & 0.97 & 0.98 & 0.98 & 0.98 & 0.98 \\
\hline Slovak Republic & $\mathrm{T} 2$ & 0.84 & 0.84 & 0.84 & 0.88 & 0.90 & 0.92 \\
\hline Slovak Republic & T3 & 0.88 & 0.88 & 0.87 & 0.87 & 0.87 & 0.88 \\
\hline Slovak Republic & $\mathrm{T} 4$ & 0.79 & 0.79 & 0.79 & 0.79 & 0.80 & 0.81 \\
\hline Slovak Republic & T5 & 0.27 & 0.30 & 0.34 & 0.45 & 0.55 & 0.65 \\
\hline Spain & T1 & 0.96 & 0.96 & 0.96 & 0.96 & 0.96 & 0.96 \\
\hline Spain & $\mathrm{T} 2$ & 0.94 & 0.94 & 0.94 & 0.94 & 0.94 & 0.94 \\
\hline Spain & T3 & 0.36 & 0.36 & 0.38 & 0.39 & 0.40 & 0.39 \\
\hline Spain & T4 & 0.81 & 0.80 & 0.80 & 0.80 & 0.80 & 0.80 \\
\hline Spain & T5 & 0.15 & 0.16 & 0.19 & 0.29 & 0.43 & 0.51 \\
\hline Romania & T1 & 0.95 & 0.95 & 0.94 & 0.94 & 0.94 & 0.95 \\
\hline Romania & $\mathrm{T} 2$ & 0.92 & 0.93 & 0.94 & 0.96 & 0.97 & 0.98 \\
\hline Romania & T3 & 0.64 & 0.64 & 0.63 & 0.62 & 0.61 & 0.60 \\
\hline Romania & T4 & 0.70 & 0.72 & 0.74 & 0.76 & 0.77 & 0.77 \\
\hline Romania & T5 & 0.18 & 0.20 & 0.22 & 0.42 & 0.61 & 0.66 \\
\hline
\end{tabular}

Continued Table A.2 


\begin{tabular}{|l|c|c|c|c|c|c|c|}
\hline \multicolumn{1}{|c|}{$\mathbf{1}$} & $\mathbf{2}$ & $\mathbf{3}$ & $\mathbf{4}$ & $\mathbf{5}$ & $\mathbf{6}$ & $\mathbf{7}$ & $\mathbf{8}$ \\
\hline France & $\mathrm{T} 1$ & 0.99 & 0.99 & 0.99 & 0.99 & 0.99 & 0.99 \\
\hline France & $\mathrm{T} 2$ & 0.83 & 0.83 & 0.83 & 0.83 & 0.83 & 0.82 \\
\hline France & $\mathrm{T} 3$ & 0.57 & 0.57 & 0.58 & 0.58 & 0.57 & 0.57 \\
\hline France & $\mathrm{T} 4$ & 0.97 & 0.97 & 0.97 & 0.97 & 0.95 & 0.95 \\
\hline France & $\mathrm{T} 5$ & 0.17 & 0.20 & 0.24 & 0.40 & 0.55 & 0.63 \\
\hline Poland & $\mathrm{T} 1$ & 0.96 & 0.95 & 0.95 & 0.95 & 0.95 & 0.95 \\
\hline Poland & $\mathrm{T} 2$ & 0.77 & 0.80 & 0.82 & 0.84 & 0.84 & 0.86 \\
\hline Poland & $\mathrm{T} 3$ & 0.76 & 0.78 & 0.79 & 0.77 & 0.77 & 0.77 \\
\hline Poland & $\mathrm{T} 4$ & 0.74 & 0.75 & 0.75 & 0.75 & 0.74 & 0.74 \\
\hline Poland & $\mathrm{T} 5$ & 0.24 & 0.26 & 0.29 & 0.38 & 0.50 & 0.66 \\
\hline China & $\mathrm{T} 1$ & 0.99 & 0.99 & 0.99 & 0.99 & 0.99 & 0.99 \\
\hline China & $\mathrm{T} 2$ & 0.71 & 0.74 & 0.79 & 0.81 & 0.82 & 0.87 \\
\hline China & $\mathrm{T} 3$ & 0.98 & 0.97 & 0.98 & 0.98 & 0.98 & 0.98 \\
\hline China & $\mathrm{T} 4$ & 0.96 & 0.95 & 0.96 & 0.95 & 0.95 & 0.95 \\
\hline China & $\mathrm{T} 5$ & 0.04 & 0.05 & 0.06 & 0.08 & 0.14 & 0.18 \\
\hline Germany & $\mathrm{T} 1$ & 1.00 & 1.00 & 1.00 & 1.00 & 1.00 & 1.00 \\
\hline Germany & $\mathrm{T} 2$ & 0.83 & 0.83 & 0.84 & 0.86 & 0.86 & 0.87 \\
\hline Germany & $\mathrm{T} 3$ & 0.68 & 0.68 & 0.68 & 0.69 & 0.69 & 0.69 \\
\hline Germany & $\mathrm{T} 4$ & 0.92 & 0.92 & 0.92 & 0.92 & 0.90 & 0.90 \\
\hline Germany & $\mathrm{T} 5$ & 0.27 & 0.30 & 0.34 & 0.50 & 0.77 & 0.94 \\
\hline Estonia & $\mathrm{T} 1$ & 0.90 & 0.91 & 0.90 & 0.91 & 0.91 & 0.91 \\
\hline Estonia & $\mathrm{T} 2$ & 0.82 & 0.82 & 0.82 & 0.83 & 0.85 & 0.87 \\
\hline Estonia & $\mathrm{T} 3$ & 0.82 & 0.83 & 0.82 & 0.83 & 0.78 & 0.77 \\
\hline Estonia & $\mathrm{T} 4$ & 0.78 & 0.80 & 0.80 & 0.78 & 0.86 & 0.85 \\
\hline Estonia & $\mathrm{T} 5$ & 0.39 & 0.43 & 0.47 & 0.64 & 0.82 & 0.93 \\
\hline
\end{tabular}

Table A.3. Dynamics of the integrated index for assessment the country potential for investment within group of 'technology'

\begin{tabular}{|l|c|c|c|c|c|c|}
\hline & $\mathbf{2 0 1 3}$ & $\mathbf{2 0 1 4}$ & $\mathbf{2 0 1 5}$ & $\mathbf{2 0 1 6}$ & $\mathbf{2 0 1 7}$ & $\mathbf{2 0 1 8}$ \\
\hline Czech Republic & 0.7643 & 0.7729 & 0.7827 & 0.8334 & 0.8651 & 0.8965 \\
\hline Ukraine & 0.6275 & 0.6487 & 0.6634 & 0.7045 & 0.7205 & 0.7410 \\
\hline United Kingdom & 0.7280 & 0.7339 & 0.7408 & 0.7670 & 0.7996 & 0.8094 \\
\hline United States & 0.7640 & 0.7694 & 0.7797 & 0.8036 & 0.8348 & 0.8819 \\
\hline Slovak Republic & 0.7548 & 0.7562 & 0.7625 & 0.7926 & 0.8212 & 0.8503 \\
\hline Spain & 0.6423 & 0.6461 & 0.6527 & 0.6755 & 0.7039 & 0.7184 \\
\hline Romania & 0.6785 & 0.6861 & 0.6944 & 0.7410 & 0.7798 & 0.7922 \\
\hline France & 0.7055 & 0.7118 & 0.7208 & 0.7517 & 0.7785 & 0.7917 \\
\hline Poland & 0.6938 & 0.7090 & 0.7197 & 0.7375 & 0.7598 & 0.7969 \\
\hline China & 0.7377 & 0.7413 & 0.7552 & 0.7630 & 0.7748 & 0.7933 \\
\hline Germany & 0.7390 & 0.7452 & 0.7562 & 0.7934 & 0.8454 & 0.8796 \\
\hline Estonia & 0.7435 & 0.7571 & 0.7607 & 0.7962 & 0.8418 & 0.8667 \\
\hline Standotklon & 0.04603 & 0.04367 & 0.04315 & 0.04459 & 0.05038 & 0.05705 \\
\hline Rozmax & 0.1368 & 0.1268 & 0.1300 & 0.1579 & 0.1612 & 0.1781 \\
\hline
\end{tabular}

Table A.4. Dynamics of the integrated index for assessment the country potential for investment within group of 'socio-economic conditions'

\begin{tabular}{|l|c|c|c|c|c|c|}
\hline & $\mathbf{2 0 1 3}$ & $\mathbf{2 0 1 4}$ & $\mathbf{2 0 1 5}$ & $\mathbf{2 0 1 6}$ & $\mathbf{2 0 1 7}$ & $\mathbf{2 0 1 8}$ \\
\hline \multicolumn{1}{|c|}{$\mathbf{1}$} & $\mathbf{2}$ & $\mathbf{3}$ & $\mathbf{4}$ & $\mathbf{5}$ & $\mathbf{6}$ & $\mathbf{7}$ \\
\hline Czech Republic & 0.7000 & 0.7838 & 0.7754 & 0.7962 & 0.8152 & 0.8020 \\
\hline Ukraine & 0.7259 & 0.6692 & 0.7115 & 0.7767 & 0.8518 & 0.8446 \\
\hline United Kingdom & 0.7262 & 0.7582 & 0.7439 & 0.7953 & 0.7699 & 0.7430 \\
\hline United States & 0.7090 & 0.7417 & 0.7546 & 0.7043 & 0.7366 & 0.7287 \\
\hline Slovak Republic & 0.7016 & 0.6395 & 0.7404 & 0.7875 & 0.7805 & 0.6460 \\
\hline Spain & 0.6952 & 0.7383 & 0.7842 & 0.7763 & 0.7087 & 0.7565 \\
\hline
\end{tabular}

Continued Table A.4 


\begin{tabular}{|l|c|c|c|c|c|c|}
\hline \multicolumn{1}{|c|}{$\mathbf{1}$} & $\mathbf{2}$ & $\mathbf{3}$ & $\mathbf{4}$ & $\mathbf{5}$ & $\mathbf{6}$ & $\mathbf{7}$ \\
\hline Romania & 0.7855 & 0.8036 & 0.8012 & 0.8053 & 0.8014 & 0.8020 \\
\hline France & 0.6974 & 0.6726 & 0.7376 & 0.7146 & 0.7378 & 0.7462 \\
\hline Poland & 0.6795 & 0.7851 & 0.7894 & 0.7619 & 0.7782 & 0.7808 \\
\hline China & 0.8217 & 0.8261 & 0.8230 & 0.8134 & 0.7891 & 0.7897 \\
\hline Germany & 0.7020 & 0.7098 & 0.7461 & 0.7411 & 0.7367 & 0.7431 \\
\hline Estonia & 0.7871 & 0.7941 & 0.6317 & 0.7755 & 0.8218 & 0.8013 \\
\hline standotklon & 0.045194 & 0.059599 & 0.049525 & 0.034596 & 0.04192 & 0.050573 \\
\hline Rozmax & 0.1422 & 0.1866 & 0.1913 & 0.1091 & 0.1431 & 0.1986 \\
\hline
\end{tabular}

Source: developed by authors.

Table A.5. Dynamics of the integrated index for assessment the country potential for investment within group of 'infrastructures'

\begin{tabular}{|l|c|c|c|c|c|c|}
\hline & $\mathbf{2 0 1 3}$ & $\mathbf{2 0 1 4}$ & $\mathbf{2 0 1 5}$ & $\mathbf{2 0 1 6}$ & $\mathbf{2 0 1 7}$ & $\mathbf{2 0 1 8}$ \\
\hline Czech Republic & 0.7211 & 0.7233 & 0.7165 & 0.7223 & 0.7281 & 0.7516 \\
\hline Ukraine & 0.8305 & 0.8321 & 0.8363 & 0.8398 & 0.8428 & 0.8522 \\
\hline United Kingdom & 0.7606 & 0.7644 & 0.7147 & 0.7173 & 0.7180 & 0.7216 \\
\hline United States & 0.6286 & 0.6213 & 0.6313 & 0.6365 & 0.6367 & 0.6523 \\
\hline Slovak Republic & 0.7349 & 0.7422 & 0.7490 & 0.7548 & 0.7594 & 0.7715 \\
\hline Spain & 0.6371 & 0.6398 & 0.6431 & 0.6484 & 0.6519 & 0.6704 \\
\hline Romania & 0.6021 & 0.6118 & 0.6171 & 0.6192 & 0.6278 & 0.6486 \\
\hline France & 0.6502 & 0.6511 & 0.6478 & 0.6506 & 0.6581 & 0.6720 \\
\hline Poland & 0.8238 & 0.8269 & 0.8306 & 0.8333 & 0.8359 & 0.8538 \\
\hline China & 0.8366 & 0.8392 & 0.8430 & 0.8467 & 0.8497 & 0.8632 \\
\hline Germany & 0.8497 & 0.8588 & 0.8755 & 0.8876 & 0.9047 & 0.9297 \\
\hline Estonia & 0.6097 & 0.6111 & 0.6142 & 0.6158 & 0.6086 & 0.6181 \\
\hline standotklon & 0.095946 & 0.09717 & 0.098263 & 0.099553 & 0.102083 & 0.103236 \\
\hline Rozmax & 0.2476 & 0.2477 & 0.2613 & 0.2717 & 0.2961 & 0.3116 \\
\hline
\end{tabular}

Source: developed by authors.

Table A.6. Dynamics of the integrated index for assessment the country potential for investment within group of 'environment and human health'

\begin{tabular}{|l|c|c|c|c|c|c|}
\hline & $\mathbf{2 0 1 3}$ & $\mathbf{2 0 1 4}$ & $\mathbf{2 0 1 5}$ & $\mathbf{2 0 1 6}$ & $\mathbf{2 0 1 7}$ & $\mathbf{2 0 1 8}$ \\
\hline Czech Republic & 0.8677 & 0.8704 & 0.8681 & 0.8689 & 0.8717 & 0.8737 \\
\hline Ukraine & 0.8650 & 0.8605 & 0.8485 & 0.8514 & 0.8593 & 0.8620 \\
\hline United Kingdom & 0.9005 & 0.9046 & 0.9039 & 0.9038 & 0.9082 & 0.9116 \\
\hline United States & 0.9230 & 0.9269 & 0.9292 & 0.9322 & 0.9345 & 0.9369 \\
\hline Slovak Republic & 0.8577 & 0.8543 & 0.8517 & 0.8600 & 0.8608 & 0.8633 \\
\hline Spain & 0.9233 & 0.9317 & 0.9317 & 0.9438 & 0.9463 & 0.9515 \\
\hline Romania & 0.8285 & 0.8301 & 0.8342 & 0.8376 & 0.8371 & 0.8410 \\
\hline France & 0.9482 & 0.9581 & 0.9552 & 0.9632 & 0.9664 & 0.9688 \\
\hline Poland & 0.8510 & 0.8535 & 0.8543 & 0.8572 & 0.8585 & 0.8610 \\
\hline China & 0.6094 & 0.6102 & 0.6101 & 0.6124 & 0.6143 & 0.6166 \\
\hline Germany & 0.9057 & 0.9088 & 0.9073 & 0.9075 & 0.9075 & 0.9086 \\
\hline Estonia & 0.8836 & 0.8820 & 0.8979 & 0.9005 & 0.9007 & 0.9069 \\
\hline standotklon & 0.087299 & 0.089013 & 0.089218 & 0.090198 & 0.090376 & 0.090651 \\
\hline Rozmax & 0.3388 & 0.3479 & 0.3451 & 0.3508 & 0.3521 & 0.3521 \\
\hline
\end{tabular}

Source: developed by authors. 
Table A.7. Dynamics of the integrated index for assessment the country potential for investment within group of 'science and education'

\begin{tabular}{|l|c|c|c|c|c|c|}
\hline & $\mathbf{2 0 1 3}$ & $\mathbf{2 0 1 4}$ & $\mathbf{2 0 1 5}$ & $\mathbf{2 0 1 6}$ & $\mathbf{2 0 1 7}$ & $\mathbf{2 0 1 8}$ \\
\hline Czech Republic & 0.7594 & 0.7592 & 0.7761 & 0.7701 & 0.7731 & 0.7763 \\
\hline Ukraine & 0.7539 & 0.7398 & 0.7359 & 0.7204 & 0.7199 & 0.7182 \\
\hline United Kingdom & 0.7960 & 0.7972 & 0.7968 & 0.7953 & 0.7963 & 0.7972 \\
\hline United States & 0.8409 & 0.8410 & 0.8418 & 0.8421 & 0.8436 & 0.8449 \\
\hline Slovak Republic & 0.7113 & 0.7168 & 0.7372 & 0.7151 & 0.7154 & 0.7165 \\
\hline Spain & 0.7342 & 0.7333 & 0.7313 & 0.7287 & 0.7273 & 0.7278 \\
\hline Romania & 0.6859 & 0.6870 & 0.6949 & 0.6931 & 0.6934 & 0.6935 \\
\hline France & 0.8461 & 0.8470 & 0.8461 & 0.8453 & 0.8463 & 0.8466 \\
\hline Poland & 0.7315 & 0.7344 & 0.7386 & 0.7364 & 0.7373 & 0.7388 \\
\hline China & 0.4605 & 0.4820 & 0.4970 & 0.5147 & 0.5217 & 0.5467 \\
\hline Germany & 0.6689 & 0.6706 & 0.6702 & 0.6716 & 0.6730 & 0.6745 \\
\hline Estonia & 0.7517 & 0.7466 & 0.7468 & 0.7385 & 0.7411 & 0.7433 \\
\hline standotklon & 0.100317 & 0.09478 & 0.091386 & 0.087007 & 0.085854 & 0.080747 \\
\hline Rozmax & 0.3856 & 0.3650 & 0.3491 & 0.3306 & 0.3245 & 0.2999 \\
\hline
\end{tabular}

Source: developed by authors.

Ю. В. Касаєва, Сумський державний університет (Україна).

Побудова моделі оцінювання інвестиційного потенціалу країни

У статmі визначено актуальність проведення адекватного оцінювання інвестиційного потенціалу країни з метою активізації трансформаційних процесів в усіх сферах економічного та соціального життя населення. Запропоновано науково-методичний підхід до оцінювання інвестиційного потенціалу країни шляхом адаптації метрики Херста, яка грунтується на розмаху накопиченого відхилення і відображує економічну сутність поняття потенціалу. В якості часового ряду обчислення метрики Херста використано теоретичні (прогнозні) значення глобального індексу привабливості прямих іноземних інвестицій, визначені за допомогою економетричної моделі залежності результативної ознаки від п'яти інтегральних показників груп: інфраструктура, освіта та наука, екологія та здоров'я людини, технології, соціально-економічні умови. Регресійну нелінійну п'яти фракторну модель залежності глобального індексу привабливості прямих іноземних інвестицій від п'яти інтегральних показників груп запропоновано представити як функцію типу функції Кобба-Дугласа. Інтегральні показники в розрізі кожної групи визначено шляхом нормалізації відносним методом вхідної інформаційної бази дослідження з подальшим зваженням методом відносного розкиду та узагальнення методом середньої арифрметичної. Практичні розрахунки проводились для таких країн, як США, Великобританія, Німеччина, Франція, Іспанія, Естонія, Чеська Республіка, Китай, Польща, Словаччина, Румунія, Україна. Встановлено, що на даний момент найбільшим інвестиційним потенціалом володіє Словаччина, Україна та Чеська Республіка, для яких значення даного показника більше 60\%. В свою чергу, найменший інвестиційний потенціал характерний для Великобританії, Іспанії та Польщі, для яких невикористані можливості в залученні інвестиційних ресурсів знаходяться на рівні менше ніж 40\%.

Ключові слова: інвестиційний потенціал, інвестиційна привабливість, метрика Херста, прямі іноземні інвестиції, регресійний аналіз, функція Кобба-Дугласа.

Manuscript received: 20.09.2019.

(C) The author(s) 2019. This article is published with open access at Sumy State University. 